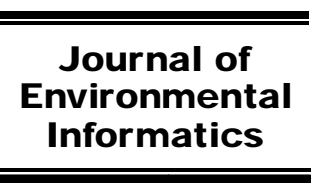

www.iseis.org/jei

\title{
Hemicellulose-Based Absorbent Toward Dye: Adsorption Equilibrium and Kinetics Studies
}

\author{
J. Zhang ${ }^{1,2}, \mathrm{H} . \mathrm{Xiao}^{2, * 3}$, and Y. Zhao ${ }^{3}$ \\ ${ }^{1}$ Liaoning Key Laboratory of Pulp and Paper Engineering, Dalian Polytechnic University, Dalian 116034, China \\ ${ }^{2}$ Department of Chemical Engineering, University of New Brunswick, Fredericton E3B 5A3, Canada \\ ${ }^{3}$ School of Environmental Science \& Engineering, North China Electric Power University, Baoding 071003, China
}

Received 8 Janunary 2013; revised 1 November 2013; accepted 16 March 2014; published online 2 August 2014

\begin{abstract}
Exploitation of biomaterials derived from renewable resources as absorbents for the removal of dyes from industrial effluents is of great importance. In this work, the efficiency of the hemicellulose-based absorbent for the adsorption of methylene blue dyes was systematically examined. It was found that the hemicellulose-based absorbent removed the dyes from aqueous solution very effectively. The study on the kinetics of methylene blue onto hemicellulose-based absorbent showed that experimental data followed a pseudo-second-order model, suggesting that the adsorption process was controlled by chemical-sorption. The equilibrium data was also fitted to the two isotherm models, Langmuir and Freundlich ones; and it was found that Langmuir model presented the best fit, showing the maximum adsorption capacity of $39.22 \mathrm{mg} / \mathrm{g}$ at $25^{\circ} \mathrm{C}$. The thermodynamic parameters, including the standard enthalpy, entropy and free energy obtained from this work, indicated that the adsorption of methylene blue onto hemicellulose based absorbent is an endothermic and spontaneous process. Overall, the adsorption process of methylene blue to hemicellulose-based absorbent is a combination of chemical-sorption and physical-sorption.
\end{abstract}

Keywords: hemicellulose, methylene blue, adsorption, kinetics, equilibrium, thermodynamic

\section{Introduction}

Dyes as organic pollutants, form a major class of environment contaminants. The complex structures and xenobiotic properties of dyes make them extremely difficult to degrade (Parida et al., 2011). Dyes are harmful to flora and fauna, and some of the organic dyes and their products have a mutagenic or carcinogenic influence on human beings (Aksu, 2005). The growing concern over the environmental issues raised by the release and use of dyes have led to the research on exploring methods of treatment, and developing novel materials that are able to tackle these environmental problems (Demirbas et al., 2008).

Methylene blue (MB), an organic dye, has wide applications (Sheng et al., 2009). Due to its known strong adsorption onto solids, MB often serves as a model compound for studying the removal of dyes and organic contaminants from aqueous solution (Hameed et al., 2007). Although not strongly poisonous, MB still possesses some harmful effects on human beings (Hajjaji and El Arfaoui, 2009). Owing to these harmful effects on humans, it is necessary to remove MB fr-

* Corresponding author. Tel.: +1 506 4533532; fax: +1 5064533591.

E-mail address: hxiao@unb.ca (H. Xiao).

ISSN: 1726-2135 print/1684-8799 online

(C) 2014 ISEIS All rights reserved. doi: 10.3808/jei.201400270 om aqueous solution.

Hemicelluloses are a class of hetero-polysaccharides present in the cell wall of wood and annual plants together with cellulose and lignin. Hemicelluloses, comprising the noncellulose cell-wall polysaccharides of plants, are the second most abundant polysaccharide in nature, representing about 20 to $35 \%$ of lignocellulosic biomass (Coviello et al., 2007; Peng et al., 2011). Recently, the importance of hemicellulose-based macromolecules and materials has been increasingly emphasized (Petzold et al., 2006; Schwikal et al., 2006). Due to their inherent hydrophilicity, low toxicity, biodegradability, and biocompatibility, the formation of latex is a potential area of application for hemicelluloses and their derivatives (Ebringerova, 2006; Coviello et al., 2007). These functional derivatives are found to be widely used in the food exploration, paper, textile, heavy metal removal and paint industries (Methacanon et al., 2003; Heinze and Koschella, 2005; Chen et al., 2009). Our preliminary results indicated that the efficiency of hemicellulose-containing latex for the removal of $\mathrm{MB}$ from aqueous solutions was good.

In this regard, in order to develop more efficient processes for preparing functional hemicellulose-based adsor- bent, the present work focused on the investigation of the equilibrium, thermodynamics and kinetics of MB adsorption from aqueous solution using hemicellulose-based latexes as adsorbents. 


\section{Experimental}

\subsection{Preparation of Hemicellulose-Based Adsorbent}

Hemicellulose used in this work was the one isolated $\mathrm{fr}$ om pre-hydrolysis liquor (PHL) of the kraft-based dissolving pulp production process (Liu et al., 2011). All chemicals and reagents used for experiments and analysis were analytical grade and purchased from Sigma Chemical Reagent Co. Ltd., Canada. 3 g Hemicellulose were mixed with 0.3 g sodium dodecyl sulfate for $1 \mathrm{~h}$, and then heated to $65^{\circ} \mathrm{C}$; followed by the addition of monomer ( $3 \mathrm{~g}$ butyl acrylate and $12 \mathrm{~g}$ acrylamide) and initiator (0.2 g ammounium persulfate) while $\mathrm{N}_{2}$ was purged through the flask. The polymerization in the presence of hemicellulose proceeded for $2 \mathrm{~h}$ under constant stirring with the rate of $500 \mathrm{rpm}$ at $70{ }^{\circ} \mathrm{C}$. The hemicellulosebased absorbent was obtained after dried in an oven at $90{ }^{\circ} \mathrm{C}$ for $24 \mathrm{~h}$ and kept in tightly closed bottles for further analysis.

\subsection{Adsorption Procedure}

The cationic dye, MB (Sigma-Aldrich, Germany) was used as an adsorbate. A series of stock solutions of MB (100 $\mathrm{mg} / \mathrm{L}$ ) were prepared and further diluted to the required concentration (50 and $100 \mathrm{ppm}$ ) prior to use. Batch adsorption was performed in a set of $20-\mathrm{mL}$ vials containing $10 \mathrm{~mL}$ of MB solution with various initial concentrations. The amount of $0.01 \mathrm{~g}$ hemicellulose-based adsorbent was added and equilibrated at different temperatures $\left(25,35\right.$ and $\left.45^{\circ} \mathrm{C}\right)$ in a temperature-controlled water bath shaker at $120 \mathrm{rpm}$. After adsorption equilibrium was achieved, the final concentration of MB in the solution was measured using an UV-visible spectrophotometer (Geneys 10S, Thermo Electron $\mathrm{C}_{0}$ ) at $664 \mathrm{~nm}$. The adsorbed capacity $\left(\mathrm{Q}_{\mathrm{e}}\right)$ and the removal efficiency $(\mathrm{R})$ of MB adsorbed onto diatomite were calculated according to the following equations:

$Q_{e}=\frac{\left(C_{0}-C_{e}\right) \times V}{M}$

$R=\frac{\left(C_{0}-C_{e}\right) \times 100}{C_{0}}$

where $\mathrm{Q}_{\mathrm{e}}$ is the adsorption capacity at equilibrium, $\mathrm{mg} / \mathrm{g}$; $\mathrm{R}$ is the removal efficiency, \%; $\mathrm{C}_{0}$ and $\mathrm{C}_{\mathrm{e}}$ are the initial and equilibrium concentrations of $\mathrm{MB}$ in the solution, $\mathrm{mg} / \mathrm{L} ; \mathrm{V}$ is the volume of solution, $\mathrm{L}$; $\mathrm{M}$ is the mass of adsorbent, $\mathrm{g}$ (Liu et al., 2012).

\subsection{Adsorption Kinetics}

Kinetic studies were carried out in vial which contained the fixed amount of adsorbent $(0.01 \mathrm{~g})$ and $10 \mathrm{~mL}$ of $\mathrm{MB}$ solution with different concentrations (100 and $50 \mathrm{ppm}$ ) at $25{ }^{\circ} \mathrm{C}$. The prediction of adsorption rate is important for designing batch adsorption systems. In order to clarify the adsorption kinetics of MB onto hemicellulose-based adsorbent, the pseudo-first-order (Malash and El-Khaiary, 2010), pseudo-second-order (Han et al., 2009) and intraparticle diffusion (Mahmoodi et al., 2012) models were used to understand the adsorption dynamics in relation to time for the MB and adsorbent system. These models can be described as follows:

$\ln \left(Q_{e}-Q_{t}\right)=\ln Q_{e}-K_{1} t$

$\frac{t}{Q_{t}}=\frac{1}{K_{2} Q_{e}^{2}}+\frac{1}{Q_{e}} t$

$Q_{t}=K_{i} t^{1 / 2}+C$

where $\mathrm{Q}_{\mathrm{t}}$ is the amount of adsorbed $\mathrm{MB}$ onto adsorbent at $\mathrm{t}$ moment, mg/g; $\mathrm{K}_{1}(1 / \mathrm{min}), \mathrm{K}_{2}(\mathrm{~g} /(\mathrm{mg} \cdot \mathrm{min})), \mathrm{K}_{\mathrm{i}}\left(\mathrm{mg} /\left(\mathrm{g} \cdot \mathrm{min}^{1 / 2}\right)\right)$ are the rate constants of the adsorption in pseudo-first-order (Equation (3)), pseudo-seconde-order (Equation (4)) and intraparticle diffusion (Equation (5)), respectively.

\subsection{Adsorption Isotherm}

Isotherm studies were carried out in vials where a fixed mass $0.01 \mathrm{~g}$ of adsorbent was introduced into $10 \mathrm{~mL}$ of $\mathrm{MB}$ solution with different concentrations at 25,35 and $45^{\circ} \mathrm{C}$.

Adsorption isotherms are used to express the surface properties and affinity of the adsorbent and can also be used to compare the adsorption capacities of the adsorbent for $\mathrm{MB}$ in aqueous solutions. In this study, the two well-known adsorption isotherm models, Langmuir and Freundlich (Shawabkeh and Tutunji, 2003) models were selected to fit the equilibrium data. The parameters obtained from the different models provide important information on the sorption mechanisms. The Langmuir model (Equation (6)) (Langmuir, 1918) and Freundlich model (Equation (7)) (Freundlich, 1932) are as follows:

$\frac{C_{e}}{Q_{e}}=\frac{C_{e}}{Q_{\max }}+\frac{1}{Q_{\max } K_{L}}$

$\ln Q_{e}=\ln K_{F}+\frac{1}{n} \ln C_{e}$

where $\mathrm{Q}_{\max }$ is the maximum adsorption capacity, $\mathrm{mg} / \mathrm{g}$; $\mathrm{K}_{\mathrm{L}}$ is a Langmuir constant relate to the affinity of the binding sites and energy of adsorption, $\mathrm{L} / \mathrm{g} ; \mathrm{K}_{\mathrm{F}}$ is a Freundlich constant related to adsorption capacity, L/g; $1 / \mathrm{n}$ is an empirical parameter related to adsorption intensity.

\subsection{Adsorption Thermodynamics}

Thermodynamic parameters including the change in the standard free energy ( $\Delta G$ ), the standard enthalpy ( $\Delta H$ ) and the standard entropy ( $\Delta S$ ) were calculated using the follow- 
ing equations (Hsu et al., 2008):

$\Delta G=-R T \ln K_{L}$

$\Delta G=\Delta H-T \Delta S$

$\ln K_{L}=\frac{\Delta S}{R}-\frac{\Delta H}{R T}$

where $\Delta G$ is the standard free energy, $\mathrm{kJ} / \mathrm{mol}$; $\mathrm{R}$ is the universal gas constant, $8.314 \mathrm{~J} /(\mathrm{mol} \cdot \mathrm{K})$; $\mathrm{T}$ is the absolute solution temperature, $\mathrm{K} ; \Delta H$ is the standard enthalpy, $\mathrm{kJ} / \mathrm{mol} ; \Delta S$ is the standard entropy, $\mathrm{J} / \mathrm{K}$.

\section{Results and Discussion}

\subsection{The Efficiency of MB Adsorption onto the Hemicellu- lose-Based Adsorbent}

The effect of the hemicellulose-based adsorbent dosage on $\mathrm{MB}$ adsorption at $25{ }^{\circ} \mathrm{C}$ was investigated and the results are depicted in Figure 1.

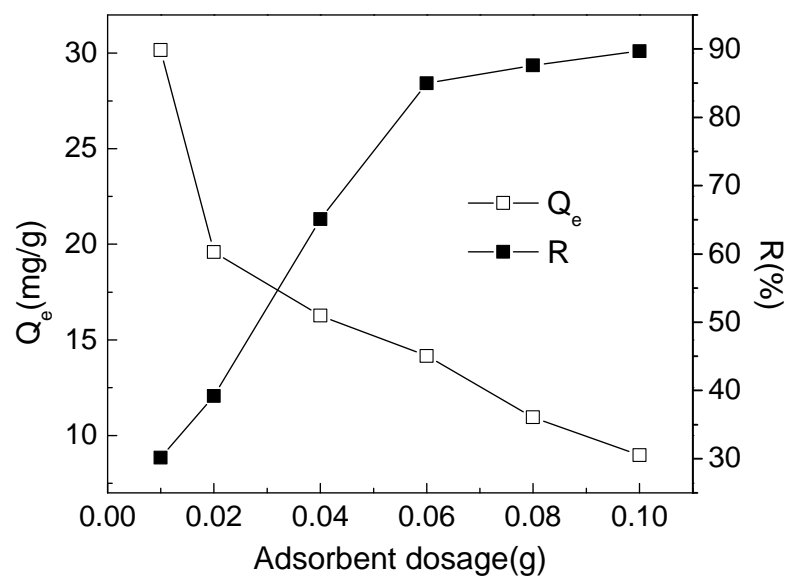

Figure 1. Effect of absorbent dosage on MB adsorption.

Figure 1 shows that the MB removal efficiency increased while the adsorption capacity $\left(\mathrm{Q}_{\mathrm{e}}\right)$ decreased with the increase of the hemicellulose-based adsorbent dosage. The maximum capacity and removal efficiency were $30.16 \mathrm{mg} / \mathrm{g}$ and $89.68 \%$, respectively. It is attributed to more surface area and active sites provided by hemicellulose-based adsorbent at a relatively high dosage. In the current system, the MB amount in aqueous solution was fixed, so that the adsorption capacity in terms of per gram absorbent deceased to some extent with the increase of the dosage of hemicellulose-based absorbent.

\subsection{Adsorption Kinetics}

Kinetic studies are important to understand the dynamic of the adsorption in terms of order of the rate constant
(Cazetta et al., 2011). In order to examine the controlling mechanism of the adsorption process, pseudo-first-order model, pseudo-second-order model and intraparticle diffusion model were applied to analyze the experimental data at two levels of initial MB concentrations (50 and 100 ppm). The corresponding plots at both concentrations are shown in Figures 2, 3 and 4, respectively. The kinetic parameters obtained from kinetic plots and model equations (Equations (3) to (5)) are presented in Table 1.

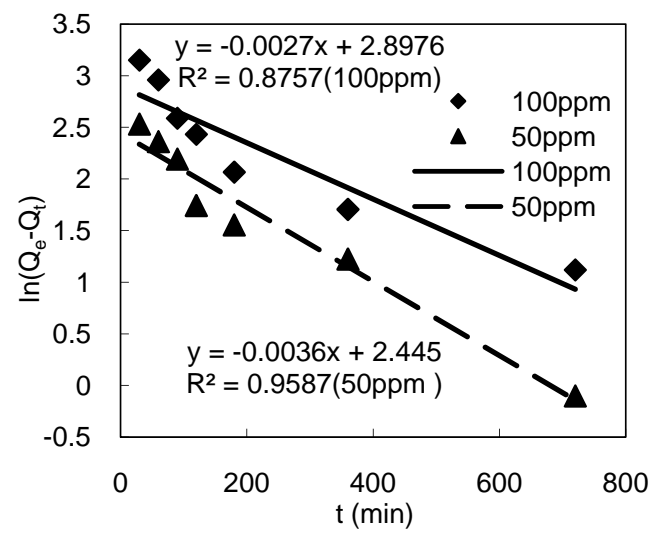

Figure 2. Pseudo-first-order kinetic plots.

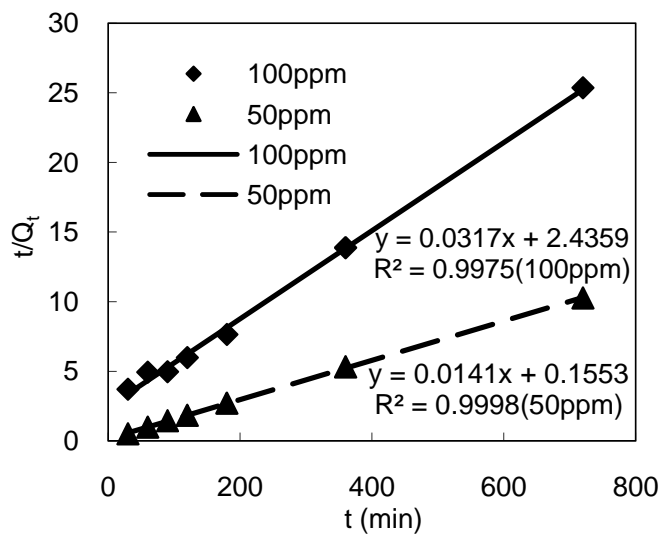

Figure 3. Pseudo-second-order kinetic plots.

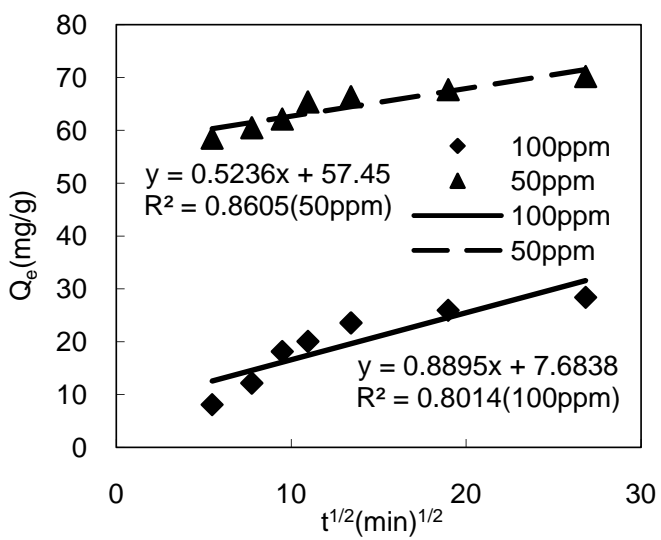

Figure 4. Intraparticle diffusion kinetic plots. 
Table 1. Adsorption Kinetic Parameters of MB on Absorbent

\begin{tabular}{llll}
\hline MB concentration & & $50 \mathrm{ppm}$ & $100 \mathrm{ppm}$ \\
\hline Pseudo-first-order & $\mathrm{Q}_{\mathrm{e}}$ exp. (mg/g) & 71.10 & 30.16 \\
& $\mathrm{Q}_{\mathrm{e} 1} \mathrm{cal} .(\mathrm{mg} / \mathrm{g})$ & 11.53 & 18.13 \\
& $\mathrm{~K}_{1}(1 / \mathrm{min})$ & 0.0036 & 0.0027 \\
& $\mathrm{R}_{1}{ }^{2}$ & 0.9587 & 0.8757 \\
Pseudo-second-order & $\mathrm{Q}_{\mathrm{e} 2} \mathrm{cal} .(\mathrm{mg} / \mathrm{g})$ & 70.92 & 31.54 \\
& $\mathrm{~K}_{2}(\mathrm{~g} /(\mathrm{mg} \cdot \mathrm{min}))$ & 0.0013 & 0.0004 \\
& $\mathrm{R}_{2}{ }^{2}$ & 0.9998 & 0.9975 \\
Intraparticle diffusion & $\mathrm{K}_{\mathrm{i}}\left(\mathrm{mg} /\left(\mathrm{g} \cdot \mathrm{min}^{1 / 2}\right)\right)$ & 0.5236 & 1.0748 \\
& $\mathrm{C}$ & 57.45 & 4.57 \\
& $\mathrm{R}_{3}{ }^{2}$ & 0.8605 & 0.8485 \\
\hline
\end{tabular}

As can be seen from Figure 2 and Table 1, the experimental $\mathrm{Q}_{\mathrm{e}}$ is not in agreement with calculated $\mathrm{Q}_{\mathrm{e} 1}$ and the coefficients of determination $\mathrm{R}_{1}^{2}$ (0.9587 and 0.8757) are low. Accordingly, the adsorption of $\mathrm{MB}$ onto the adsorbent did not follow the pseudo-first-order kinetic model. However the $\mathrm{R}_{2}{ }^{2}$ values were in range of 0.9975 to 0.9998 and the theoretical $\mathrm{Q}_{\mathrm{e} 2}$ values were closer to the experimental $\mathrm{Q}_{\mathrm{e}}$ values, shown in Figure 3 and Table 1. The results demonstrated that the adsorption followed the pseudo-second-order kinetic model well. Figure 4 shows the plots of $\mathrm{Q}_{\mathrm{t}}$ versus $\mathrm{t}^{1 / 2}$. The data obtained from Figure 4 showed the two stage of adsorption. The first stage is the instantaneous adsorption, was completed within the first $3 \mathrm{~h}$. The second stage is the gradual adsorption where the intraparticle diffusion is the rate limiting. Both the linear lines did not pass through the origin which suggested that the intraparticle diffusion was not the only limiting mechanism in the adsorption process (Morris and Weber, 1962). The $\mathrm{R}_{3}{ }^{2}$ values shown in Table 3 were lower than those for pseudo-firstorder and pseudo-second-order models. Base on these results, it can be concluded that the pseudo-second-order kinetic model provided a good correlation for the adsorption of MB onto the adsorbent in contrast to the pseudo-first-order model and intraparticle diffusion model. This also suggested that the rate of the adsorption process was preferably controlled by chemical-sorption (Ho et al., 2000; Tan et al., 2008).

\subsection{Adsorption Isotherm}

The adsorption isotherms show how the adsorbates are distributed between the solution and the absorbent at the equilibrium conditions. Moreover, the adsorption isotherms can reveal the effect of equilibrium concentration on the adsorption capacity at different temperatures as well (Hameed et al., 2008).

The effect of MB equilibrium concentration on the adsorption capacity of the hemicellulose-based absorbent was carried out at 25, 35 and $45^{\circ} \mathrm{C}$ and the results are shown in Figure 5 .

It is clear that the absorption capacity of the hemicellulose-based adsorbent increased as the temperature increased (Figure 5). This is attributed to the increasing rate of diffusion of the MB molecules, partly owing to the decrease in the viscosity of the solution (Al-Ghouti et al., 2003). The equilibri-

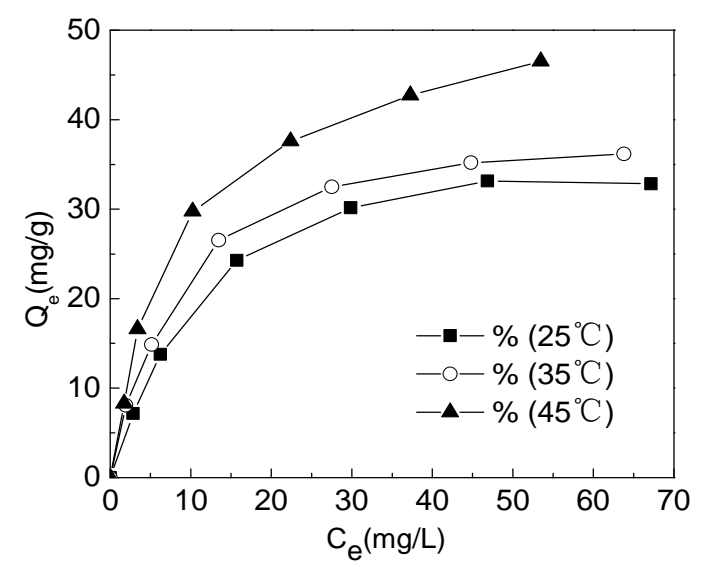

Figure 5. Adsorption isotherms for methylene blue onto the hemicellulose-based absorbent.

um adsorption amount was of MB also affected by temperature, which was increased from 32.8 to $46.5 \mathrm{mg} / \mathrm{g}$ when the temperature was raised from 25 to $45^{\circ} \mathrm{C}$. The increase of absorption amount of MB onto hemicellulose-based absorbent with the increase of temperature suggests that the adsorption is endothermic.

Langmuir and Freundlich isotherm models were used to fit the experimental data. Based on the Equations (6) and (7), the values of the models constants in addition to the values of the correlation coefficient were calculated by plotting $\ln Q_{e} / C_{e}$ versus $Q_{e}$ and $\ln Q_{e}$ versus $\ln C_{e}$ from the slope and intercept at different temperatures. Figures 6 and 7 show the linear fits of Langmuir model and Freundlich model, respecttively. The isotherm parameters are shown in Table 2.

The Langmuir model assumes that the adsorption is a process which occurs in a homogeneous surface (Kumar et al., 2010). Figure 6 showed the linear Langmuir isotherm plot and the $\mathrm{R}_{\mathrm{L}}{ }^{2}$ values at different temperatures were in range of 0.99 39 to 0.9982 . The results indicated that the adsorption of the MB onto the hemicellulose-based adsorbent fitted the langmuir model well with the characteristic of the monolayer coverage of $\mathrm{MB}$ at the outer surface. The separation factor $\left(\mathrm{D}_{\mathrm{L}}=\right.$

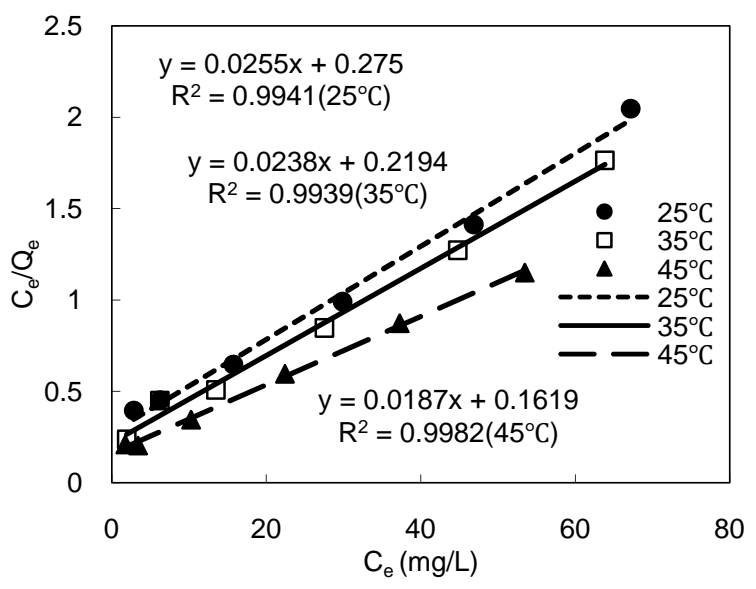

Figure 6. Linear fits of Langmuir model. 


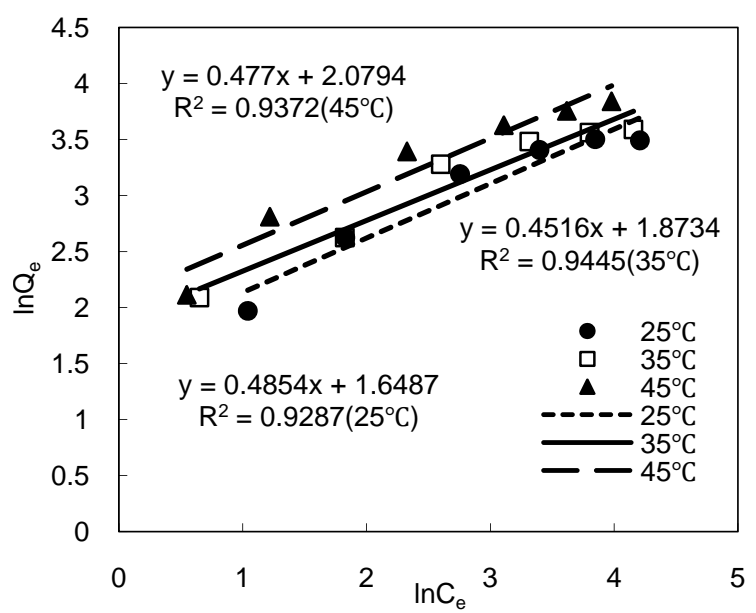

Figure 7. Linear fits of Langmuir model.

$\left.1 /\left(1+\mathrm{K}_{\mathrm{L}} \mathrm{C}_{\mathrm{e}}\right)\right)$ is an important parameter of the Langmuir isotherm that can be used to verify if the adsorption in the system is unfavorable $\left(D_{L}>1\right)$, linear $\left(D_{L}=1\right)$, favorable $\left(0<D_{L}<1\right)$ or irreversible $\left(D_{L}=0\right)$ (Weber and Chakravo, 1974). The $D_{L}$ values were in the range of 0.7967 to 0.9734 , indicating that the adsorption system is favorable.

The Freundlich model assumes a hetegeneous adsorption surface (Cazetta et al., 2011). Figure 7 indicated the linear Freundlich isotherm plot and the $\mathrm{R}_{\mathrm{F}}{ }^{2}$ values were lower than 0.9500 , revealing that the adsorption system did not follow the Freundlich model. The heterogeneity factor (n) showed whether the adsorption process is linear $(n=1)$, chemical $(n<1)$ or physical $(n>1)$. According to the results shown in Table 2, the values of $n$ were all higher than 2 at different temperatures, indicated that the adsorption is physical. Moreover the values of $\mathrm{K}_{\mathrm{F}}$ and $\mathrm{n}$ increased as the temperature increased, indicating that the adsorption was favorable at high temperature (Sharma, 2010).

\subsection{Adsorption Thermodynamics}

The thermodynamic parameters of the adsorption process of $\mathrm{MB}$ onto the adsorbent are the changes in standard enthalpy, entropy and free energy. The standard enthalpy and standard entropy parameters are calculated from the slope and intercept of the plot of $\ln \mathrm{K}_{\mathrm{L}}$ versus $1 / \mathrm{T}$ yields, respectively (Figure 8).

The values of these parameters were calculated using Equations (8), (9) and (10) at various temperatures and are shown in Table 3.

The positive $\Delta H(8.70 \mathrm{KJ} / \mathrm{mol})$ means that the adsorpti-

Table 2. Isotherm Parameters of MB onto the HemicelluloseBased Absorbent

\begin{tabular}{lllllll}
\hline \multirow{2}{*}{$/{ }^{\circ} \mathrm{C}$} & \multicolumn{3}{c}{ Langmuir } & \multicolumn{3}{c}{ Freundlich } \\
\cline { 2 - 7 } $\mathrm{Q}_{\max }(\mathrm{mg} / \mathrm{g})$ & $\mathrm{K}_{\mathrm{L}}$ & $\mathrm{R}_{\mathrm{L}}{ }^{2}$ & $\mathrm{~K}_{\mathrm{F}}$ & $\mathrm{n}$ & $\mathrm{R}_{\mathrm{F}}{ }^{2}$ \\
\hline 25 & 39.22 & 0.0927 & 0.9941 & 5.2002 & 2.06 & 0.9287 \\
35 & 42.02 & 0.1085 & 0.9939 & 6.5104 & 2.21 & 0.9445 \\
45 & 53.48 & 0.1155 & 0.9982 & 7.9997 & 2.10 & 0.9372 \\
\hline
\end{tabular}

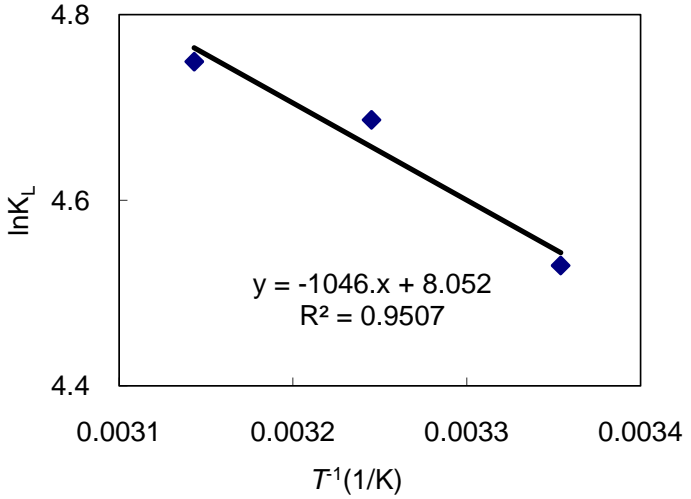

Figure 8. Plot of $\ln K_{\mathrm{L}}$ versus $1 / \mathrm{T}$.

on process was carried out as endothermic at 25 to $45^{\circ} \mathrm{C}$. The positive value of $\Delta S(0.0670 \mathrm{KJ} / \mathrm{mol})$ indicated the increased randomness at the solid-liquid interface and the affinity of the adsorbent for the MB (Nasuha and Hameed, 2011). The values of $\Delta G$ were all negative at difference temperatures, indicating that the adsorption was spontaneous. In general, the values of $\Delta G$ between 0 and $-20 \mathrm{KJ} / \mathrm{mol}$ indicated that the adsorption process is physical-sorption, while the value in between -400 and $-80 \mathrm{KJ} / \mathrm{mol}$ correspond to chemical-sorption (Weng et al., 2009; Fernandes et al., 2010). The values of $\Delta G$ suggested the adsorption is a physical-sorption process. The increase in negative $\Delta G$ value parallel to temperature revealed that adsorption of MB onto the adsorbent became more favorable at higher temperature. This was previously confirmed by the isotherm experiments at different temperatures.

Table 3. Adsorption Thermodynamics Data of MB onto the Absorbent

\begin{tabular}{llll}
\hline $\mathrm{T} /{ }^{\circ} \mathrm{C}$ & $\Delta \mathrm{H}(\mathrm{KJ} / \mathrm{mol})$ & $1 \mathrm{~S}(\mathrm{KJ} / \mathrm{mol})$ & $\Delta \mathrm{G}(\mathrm{KJ} / \mathrm{mol})$ \\
\hline 25 & 8.70 & 0.0670 & -11.26 \\
35 & & & -11.93 \\
45 & & & -12.60 \\
\hline
\end{tabular}

\section{Conclusions}

In this study, the hemicellulose-based absorbent for the removal of $\mathrm{MB}$ was developed along with the investigation of the adsorption equilibrium as well as the thermodynamic and the kinetics of adsorption using a batch system. The results showed that the as-prepared hemicellulose-based adsorbent presented very efficient absorption toward MB. The kinetic analysis demonstrated that the adsorption process follows the pseudo-second-order model well, which suggests that the process was controlled by chemical-sorption. Based on the linear models of Langmiur and Freunlich, the Langmuir isotherm model was better fitted to the experimental data, showing the maximum monolayer adsorption capacity of $39.22 \mathrm{mg} / \mathrm{g}$ at $25{ }^{\circ} \mathrm{C}$. The thermodynamic parameters indicated that the adsorption of MB onto the hemicellulose-based adsorbent was an endothermic and spontaneous process. The values of $\Delta G$ suggested the adsorption is a physical-sorption process. The above results confirmed that the hemicellulsoe-based adsor- 
bent is very promising absorbent for the removal of the dyes like MB from contaminated aqueous solutions; and the adsorption process combines physical-sorption and chemicalsortion.

Acknowledgement. Authors are grateful to the Innovative Green Wood Fibre Products-NSERC Strategic Network (Canada), NSF China (No. 51379077), NSF China (No. 31200456) and program for high school excellent talent for Liaoning Province for funding.

\section{References}

Al-Ghouti, M.A., Khraisheh, M.A.M., Allen, S.J., and Ahmad, M.N. (2003). The removal of dyes from textile wastewater: A study of the physical characteristics and adsorption mechanisms of diatomaceous earth. J. Environ. Manage., 69, 229-238. http://dx.doi. org/10.1016/j.jenvman.2003.09.005

Aksu, Z. (2005). Application of biosorption for the removal of organic pollutants: A review. Process Biochem., 40(3-4), 997-1026. http://dx.doi.org/10.1016/j.procbio.2004.04.008

Cazetta, A.L., Vargas, A.M.M., Nogami, E.M., Kunita, M.H., Guilherme, M.R., Martins, A.C., and Almeida, V.C. (2011). Na$\mathrm{OH}$-activated carbon of high surface area produced from coconut shell: Kinetics and equilibrium studies from the methylene blue adsorption. Chem. Eng. J., 174(1), 117-125. http://dx.doi.org/10.1 016/j.cej.2011.08.058

Chen, S.Y., Zou, Y., Yan, Z.Y., Shen, W., Shi, S.K., Zhang, X., and Wang, H.P. (2009). Carboxymethylated-bacterial cellulose for copper and lead ion removal. J. Hazard. Mater., 161(2-3), 1355-1359. http://dx.doi.org/10.1016/j.jhazmat.2008.04.098

Coviello, T., Matricardi, P., Marianecci, C., and Alhaique, F. (2007). Polysaccharide hydrogels for modified release formulations. $J$. Control. Release., 119(1), 5-24. http://dx.doi.org/10.1016/j.jconrel. 2007.01.004

Demirbas, E., Kobya, M., and Sulak, M.T. (2008). Adsorption kinetics of a basic dye from aqueous solutions onto apricot stone activated carbon. Bioresour. Technol., 99(13), 5368-5373. http://dx. doi.org/10.1016/j.biortech.2007.11.019

Ebringerova, A. (2006). Structural diversity and application potential of hemicelluloses. Macromol. Symp., 232, 1-12. http://dx.doi.org/ 10.1002/masy.200551401

Fernandes, A.N., Almeida, C.A.P., Debacher, N.A., and Sierra, M.M. D. (2010). Isotherm and thermodynamic data of adsorption of methylene blue from aqueous solution onto peat. J. Mol. Struct., 982(1-3), 62-65. http://dx.doi.org/10.1016/j.molstruc.2010.08.006

Freundlich, H. (1932). Of the adsorption of gases. Section II. Kinetics and energetics of gas adsorption. Introductory paper to section II. Trans. Faraday Soc., 28, 195-201. http://dx.doi.org/10.1039/TF93 22800195

Hajjaji, M., and El Arfaoui, H. (2009). Adsorption of methylene blue and zinc ions on raw and acid-activated bentonite from Morocco. Appl. Clay Sci., 46(4), 418-421. http://dx.doi.org/10.1016/j.clay. 2009.09.010

Hameed, B.H., Ahmad, A.L., and Latiff, K.N.A. (2007). Adsorption of basic dye (methylene blue) onto activated carbon prepared from rattan sawdust. Dyes Pigments, 75(1), 143-149. http://dx.doi. org/ 10.1016/j.dyepig.2006.05.039

Hameed, B.H., Tan, I.A.W., and Ahmad, A.L. (2008). Adsorption isotherm, kinetic modeling and mechanism of 2,4,6-trichlorophenol on coconut husk-based activated carbon. Chem. Eng. J., 144(2), 235-244. http://dx.doi.org/10.1016/j.cej.2008.01.028

Han, R.P., Zhang, J.J., Han, P., Wang, Y.F., Zhao, Z.H., and Tang,
M.S. (2009). Study of equilibrium, kinetic and thermodynamic parameters about methylene blue adsorption onto natural zeolite. Chem. Eng. J., 145(3), 496-504. http://dx.doi.org/10.1016/j.cej. 2008.05.003

Heinze, T., and Koschella, A. (2005). Carboxymethyl ethers of cellulose and starch - A review. Macromol. Symp., 223, 13-39. http: //dx. doi.org/10.1002/masy.200550502

Ho, Y.S., McKay, G., Wase, D.A.J., and Forster, C.F. (2000). Study of the sorption of divalent metal ions on to peat. Adsorpt. Sci. Technol., 18(7), 639-650. http://dx.doi.org/10.1260/02636170014 93693

Hsu, T.C., Yu, C.C., and Yeh, C.M. (2008). Adsorption of $\mathrm{Cu}^{2+}$ from water using raw and modified coal fly ashes. Fuel, 87(7), 13551359. http://dx.doi.org/10.1016/j.fuel.2007.05.055

Kumar, P.S., Ramalingam, S., Senthamarai, C., Niranjanaa, M., Vijayalakshmi, P., and Sivanesan, S. (2010). Adsorption of dye from aqueous solution by cashew nut shell: Studies on equilibrium isotherm, kinetics and thermodynamics of interactions. Desalination, 261(1-2), 52-60. http://dx.doi.org/10.1016/j.desal.2010.05.0 32

Langmuir, I. (1918). The adsorption of gases on plane surfaces of glass, mica and platinum. J. Am. Chem. Soc., 40(9), 1361-1403. http://dx.doi.org/10.1021/ja02242a004

Liu, Z.H., Ni, Y.H., Fatehi, P., and Saeed, A. (2011). Isolation and cationization of hemicelluloses from pre-hydrolysis liquor of kraftbased dissolving pulp production process. Biomass Bioenergy, 35 (5), 1789-1796. http://dx.doi.org/10.1016/j.biombioe.2011.01.008

Liu, T.H., Li, Y.H., Du, Q.J., Sun, J.K., Jiao, Y.Q., Yang, G.M., Wu, D. (2012). Adsorption of methylene blue from aqueoussolution by graphene. Colloids Surf B Biointerfaces, 90, 197-203. http://dx.doi. org/10.1016/j.colsurfb.2011.10.019

Mahmoodi, N.M., Hayati, B., and Arami, M. (2012). Kinetic, equilibrium and thermodynamic studies of ternary system dye removal using a biopolymer. Ind. Crops Prod., 35(1), 295-301. http://dx.doi. org/10.1016/j.indcrop.2011.07.015

Malash, G.F., and El-Khaiary, M.I. (2010). Methylene blue adsorption by the waste of Abu-Tartour phosphate rock. J. Colloid Interface Sci., 348(2), 537-545. http://dx.doi.org/10.1016/j.jcis. 2010.05. 005

Methacanon, P., Chaikumpollert, O., Thavorniti, P., and Suchiva, K. (2003). Hemicellulosic polymer from Vetiver grass and its physicochemical properties. Carbohyd. Polym., 54(3), 335-342. http:// dx.doi.org/10.1016/S0144-8617(03)00182-6

Morris, J.C., and Weber, W.J. (1962). The use of adsorption for the removal of biologically-resistant pollutants from wastewaters. $J$. Water Pollut. Control Fed., 34(3), 235-236.

Nasuha, N., and Hameed, B.H. (2011). Adsorption of methylene blue from aqueous solution onto $\mathrm{NaOH}$-modified rejected tea. Chem. Eng. J., 166(2), 783-786. http://dx.doi.org/10.1016/j.cej.2010.11.0 12

Parida, K.M., Sahu, S., Reddy, K.H., and Sahoo, P.C. (2011). A kinetic, thermodynamic, and mechanistic approach toward adsorption of methylene blue over water-washed manganese nodule leached residues. Ind. Eng. Chem. Res., 50(2), 843-848. http://dx.doi. org/10.1021//e101866a

Peng, X.W., Ren, J.L., Zhong, L.X., Peng, F., and Sun, R.C. (2011). Xylan-rich hemicelluloses-graft-acrylic acid ionic hydrogels with rapid responses to $\mathrm{pH}$, salt, and organic solvents. J. Agric. Food Chem., 59(15), 8208-8215. http://dx.doi.org/10.1021/Jf201589y

Petzold, K., Schwikal, K., Gunther, W., and Heinze, T. (2006). Carboxymethyl xylan - Control of properties by synthesis. Macro- mol. Symp., 232, 27-36. http://dx.doi.org/10.1002/masy.200551404

Schwikal, K., Heinze, T., Ebringerova, A., and Petzold, K. (2006). Cationic xylan derivatives with high degree of functionalization. 
Macromol. Symp., 232, 49-56. http://dx.doi.org/10.1002/masy.200 551406

Sharma, Y.C. (2010). Optimization of parameters for adsorption of methylene blue on a low-cost activated carbon. J. Chem. Eng. Data, 55(1), 435-439. http://dx.doi.org/10.1021/Je900408s

Shawabkeh, R.A., and Tutunji, M.F. (2003). Experimental study and modeling of basic dye sorption by diatomaceous clay. Appl. Clay Sci., 24(1-2), 111-120. http://dx.doi.org/10.1016/S0169-1317(03)0 0154-6

Sheng, J.W., Xie, Y.A., and Zhou, Y. (2009). Adsorption of methylene blue from aqueous solution on pyrophyllite. Appl. Clay Sci., 46(4), 422-424. http://dx.doi.org/10.1016/j.clay.2009.10.006
Tan, I.A.W., Ahmad, A.L., and Hameed, B.H. (2008). Adsorption of basic dye on high-surface-area activated carbon prepared from coconut husk: Equilibrium, kinetic and thermodynamic studies. $J$. Hazard. Mater., 154(1-3), 337-346. http://dx.doi.org/10.1016/j.jhaz mat.2007.10.031

Weber, T.W., and Chakravo, R.K. (1974). Pore and solid diffusion models for fixed-bed adsorbers. Aiche J., 20(2), 228-238. http://dx. doi.org/10.1002/aic.690200204

Weng, C.H., Lin, Y.T., and Tzeng, T.W. (2009). Removal of methylene blue from aqueous solution by adsorption onto pine- apple leaf powder. J. Hazard. Mater., 170(1), 417-424. http://dx.doi.org/ 10.1016/j.jhazmat.2009.04.080 